Original articles

J. Perinat. Med. 17 (1989) 195

\title{
Enzyme variability and neonatal jaundice. The role of adenosine deaminase and acid phosphatase
}

\author{
Alessandro Lepore ${ }^{1}$, N. Lucarini' ${ }^{2}$, M. A. Evangelista ${ }^{1}$, G. Palombaro ${ }^{3}$, A. Londrillo ${ }^{4}$, \\ P. Ballarini ${ }^{2}$, P. Borgiani ${ }^{2}$, F. Gloria-Bottini ${ }^{5}$, and Egidio Bottini ${ }^{5}$
}

${ }^{1}$ Center of Hygiene and Preventive Medicine, U.L.S.S., Penne, ${ }^{2}$ Laboratory of Genetics, University of Camerino, School of Science, Camerino, ${ }^{3}$ Department of Obstetrics and Gynecology, U.L.S.S., Penne, ${ }^{4}$ Department of Pediatrics, U.L.S.S., Penne, ${ }^{5}$ Chair of Human Development, $2^{\text {nd }}$ University of Rome, School of Medicine, Rome, Italy

\section{Introduction}

In a recent paper we have reported an interaction between $\mathrm{ACP}_{1}$ (Erythrocyte acid phosphatase EC 3.1.3.2.) and ADA (Adenosine deaminase EC 3.5.4.4.) in relation to neonatal hyperbilirubinemia. The incidence of jaundice was much higher among newborn of $\mathrm{ACP}_{1}$ phenotype $\mathrm{BA}$ carrying $\mathrm{ADA}^{2}$ allele $(41.7 \%)$ than among other infants $(7.5 \%)$ [3]. We have now studied a new series of infants from another population: the data confirm that $\mathrm{ACP}_{1}$ phenotype $\mathrm{BA}$ carrying $\mathrm{ADA}^{2}$ allele has a very high risk of clinically relevant neonatal jaundice.

It is likely that both environmental and genetic factors influence the severity of "physiologic jaundice of newborn". As in many pathologic situations in which a multifactorial inheritance is presumed, research should be directed toward those factors which determine the "normal variability" of biochemical and physiological parameters. Human genetic polymorphisms are therefore the most important candidates for this kind of investigations.

$\mathrm{ACP}_{1}$ is an enzyme found in the cytoplasm of many tissues besides red blood cells. It is genetically distinct from acid phosphatases found in lysosomes and is polymorphic with three codominant alleles $\left(\mathrm{P}^{\mathrm{A}}, \mathrm{P}^{\mathrm{B}}\right.$ and $\left.\mathrm{P}^{\mathrm{C}}\right)$ at an autosomal locus $[11,12,20] . \mathrm{ACP}_{1}$ probably acts in vivo as a flavin mononuclectide phosphatase $[14,15,17]$. It may

\section{Curriculum vitae}

ALESSANDRO LEPORE, M.D. was born in 1930. As medical student, he prepared his thesis in the Mendel Institute of University of Rome under the direction of Prof. LUIGI GEDDA and received his $M . D$. "magna cum laude" in 1956. Dr. LEPORE is specialized in Gastroenterology and $\mathrm{Hy}$ giene. He has been Direc-

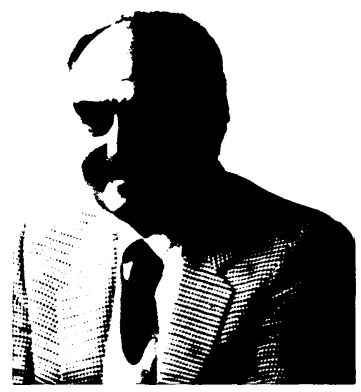
tor of the Center for Hygiene and Preventive Medicine of U.L.S.S. of Penne and his main interest is Community Medicine.

therefore modulate Krebs-cycle activity and other important enzymes such as glutathione reductase, a flavoenzyme which exert a key role in the maintenance of red cell integrity [17]. Enzymatic activity of $\mathrm{ACP}_{1}$ is modulated (activated or inhibited) by purines and inhibited by folic acid. The most important aspect of these findings is the fact that in the quantitative variation of $\mathrm{ACP}_{1}$ enzyme activity, the contribution of the alloenzymes increases in the order $\mathrm{P}^{\mathrm{A}}<\mathrm{P}^{\mathrm{B}}<\mathrm{P}^{\mathrm{C}}$ [12] whereas with the effects on purine and folic acid modulation, the alloenzyme contribution is ranked either 
$\mathrm{P}^{\mathrm{C}}<\mathrm{P}^{\mathrm{A}}<\mathrm{P}^{\mathrm{B}}$ or $\mathrm{P}^{\mathrm{B}}<\mathrm{P}^{\mathrm{A}}<\mathrm{P}^{\mathrm{C}}$. This difference in ranking indicates that the two types of activity variation represent independent effects [14].

The association previously reported $[5,6,8]$ between CA phenotype and neonatal hyperbilirubinemia has been tentatively explained by the fact that activation of $\mathrm{CA}$ by adenine is stronger as compared to other $\mathrm{ACP}_{1}$ genotypes. This would cause a reduced availability of flavin cofactors (figure 1) and a lower activity of the flavo-enzyme glutathione reductase which in turn may be reflected in a reduced red cell stability [14]. Since flavoenzymes have a central role in metabolism, modulation of coenzyme levels may have importance in many developmental processes which may influence bilirubin metabolism. Recent observations by our group seem to give support to this conjecture $[2,4]$.

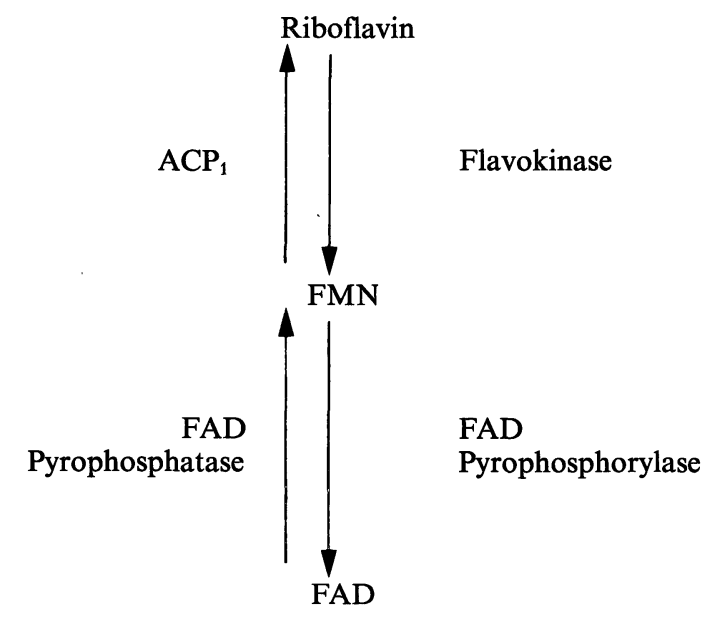

Figure 1. Scheme showing the action of $\mathrm{ACP}_{1}$ on flavin cofactors metabolism. (Slightly modified from Mansfield and Sensabough [14].)

ADA is a polymorphic enzyme which catalizes the deamination of adenosine to inosine. Its synthesis is controlled by an autosomal locus with two codominant alleles $\mathrm{ADA}^{1}$ and $\mathrm{ADA}^{2}$. The enzymatic activity decreases in the order $\mathrm{ADA}^{1}>\mathrm{ADA}^{2}[1$, $9,19]$. The study of possible interactions between $\mathrm{ACP}_{1}$ and $\mathrm{ADA}$ was suggested by the observation that while adenosine does not show appreciable effects of $\mathrm{ACP}_{1}$ activity, inosine, on the contrary, is a relatively strong activator [14].

\section{Material and methods}

\subsection{Infants from the population of Penne}

Penne is a small town in the East Side of Southern Italy. It is located in a rural area, at a distance of about two hundred kilometers from Rome. The population is very homogeneous and immigration is practically absent. These people are probably the direct descendants of the ancient Italic population called "VESTINI".

A sample of 56 children treated by phototherapy during the neonatal period $(53 \%$ of infants observed in four years) were studied. All children were born at term and weighted 2500 grams or more. Phototherapy was started at bilirubin level of $12 \mathrm{mg} / \mathrm{dl}$. The proportion of full term infants treated by phototherapy is about $15 \%$ in this population.

A control sample of 141 newborn infants without clinically relevant neonatal jaundice were also studied.

\subsection{Newborn infants from the population of Rome}

This sample has been already reported in a previous paper [3]. Two consecutive series of infants, born at term, weighting $2500 \mathrm{gr}$ or more and compatible with their mothers in $\mathrm{ABO}$ and $\mathrm{Rh}$ systems, were studied. Both $\mathrm{ADA}$ and $\mathrm{ACP}_{1}$ phenotypes were determined in 225 infants. Twenty one $(9.33 \%)$ were treated by phototherapy. In these subjects, therapy was started at bilirubin levels greater than $12 \mathrm{mg} / \mathrm{dl}$.

$\mathrm{ACP}_{1}$ and ADA phenotypes were determined by starch gel electrophoresis [12, 19] on umbilical cord blood (Rome) or venous blood (Penne).

\section{Results}

Table I shows the sample distribution of some relevant variables in infants with neonatal jaundice. In the sample from Penne, maternal age distribution is shifted towards extreme values.

Tables II and III and figure 2 show that in both populations BA phenotype carrying $\mathrm{ADA}^{2}$ allele is associated with a very high incidence of clinically relevant neonatal jaundice. However, besides this striking similarity of the $\mathrm{ACP}_{1}$ by ADA interaction in relation to neonatal jaundice the data also show differences between the two populations. In fact $\mathrm{ACP}_{1}$ phenotype $\mathrm{BA}$ not carrying $\mathrm{ADA}^{2}$ shows an incidence of jaundice much higher in the pop- 
Table I. Jaundiced infants treated by phototherapy during neonatal period from two Italian populations. Sample distribution of some relevant variables

\begin{tabular}{lccc}
\hline & & \multicolumn{2}{c}{ Population } \\
\cline { 3 - 4 } & & 56 & Rome \\
\hline Number of infants & & 51.8 & 21 \\
Sex proportion \% (males/total) & mean & 39.80 & 52.4 \\
Gestational age (weeks) & S. D. & 0.84 & 40.09 \\
& mean & 3482 & 1.84 \\
Birth weight (grams) & S. D. & 431 & 3476 \\
Maternal age & $\leqslant 25$ years \% & 46.4 & 451 \\
& $25-35$ years \% & 33.9 & 38.1 \\
& $\geqslant 35$ years \% & 19.8 & 47.6 \\
\end{tabular}

Table II. Joint distribution of $\mathrm{ACP}_{1}$ and ADA phenotypes in jaundiced and in not-jaundiced infants

\begin{tabular}{|c|c|c|c|c|c|c|c|c|c|}
\hline & & \multicolumn{8}{|c|}{ Population } \\
\hline & & \multicolumn{4}{|c|}{ Penne } & \multicolumn{4}{|c|}{ Rome } \\
\hline & & \multicolumn{2}{|c|}{$\begin{array}{l}\text { Treated infants } \\
\text { ADA }^{2} \text { allele }\end{array}$} & \multicolumn{2}{|c|}{$\begin{array}{l}\text { Untreated infants } \\
\text { ADA }^{2} \text { allele }\end{array}$} & \multicolumn{2}{|c|}{$\begin{array}{l}\text { Treated infants } \\
\text { ADA }^{2} \text { allele }\end{array}$} & \multicolumn{2}{|c|}{$\begin{array}{l}\text { Untreated infants } \\
\text { ADA }^{2} \text { allele }\end{array}$} \\
\hline & & absent & present & absent & present & absent & present & absent & present \\
\hline \multirow{6}{*}{ 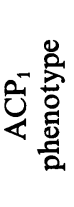 } & A & 4 & 1 & 9 & 2 & 1 & 1 & 23 & 1 \\
\hline & B & 17 & 2 & 62 & 9 & 9 & 2 & 82 & 14 \\
\hline & $\mathrm{C}$ & 1 & j & 1 & 1 & 1 & i & 1 & 1 \\
\hline & BA & 19 & 7 & 38 & 5 & 1 & 5 & 54 & 7 \\
\hline & CA & 3 & 1 & 5 & 1 & 1 & 1 & 2 & 1 \\
\hline & CB & 3 & 1 & 9 & 1 & 2 & 1 & 16 & 3 \\
\hline
\end{tabular}

Table III. Incidence of jaundice in $\mathrm{ACP}_{1}$ phenotype $\mathrm{BA}$ in relation to presence of $\mathrm{ADA}^{2}$ allele. In the sample from Penne the incidence was estimated taking into account the phenotype distributions in treated and not-treated infants and the mean incidence of jaundice in newborn infants. For independence tests actual number of observations were used

\begin{tabular}{|c|c|c|c|c|c|}
\hline & $\begin{array}{l}\text { BA not carrying } \\
\text { ADA }^{2}\end{array}$ & $\begin{array}{l}\text { BA carrying } \\
\text { ADA }^{2}\end{array}$ & $\begin{array}{l}\text { Other } \mathrm{ACP}_{1} \\
\text { phenotypes }\end{array}$ & $\begin{array}{l}\text { Whole } \\
\text { sample }\end{array}$ & $\begin{array}{l}\text { Significance (Chi) } \\
\text { square test of } \\
\text { independence) }\end{array}$ \\
\hline Rome & $1.8 \%$ & $41.7 \%$ & $9.5 \%$ & $9.3 \%$ & 0.001 \\
\hline Penne & $18.2 \%$ & $38.4 \%$ & $12.0 \%$ & $15.0 \%$ & 0.025 \\
\hline
\end{tabular}

Three way contineency table analysis by log-linear model [18]

$\mathrm{X}=\mathrm{ACP}_{1}$-ADA joint phenotype FACTOR (categories: $\mathrm{ACP}_{1} \mathrm{BA}^{-\mathrm{ADA}^{2} \text { carrier/other types) }}$

Y : JAUNDICE FACTOR (categories: treated by phototherapy/not treated)

$\mathrm{Z}=$ POPULATION FACTOR (categories: Penne/Roma).

test

$\mathrm{X}-\mathrm{Y}-\mathrm{Z}$ interaction

independence of factors $X$ and $Y$ given the level of $Z$

independence of factors $X$ and $Z$ given the level of $Y$
G (Williams) D.F.

0.828

14.574

1.380
1

2

2
Significance

N.S.

$<0.001$

N.S. 


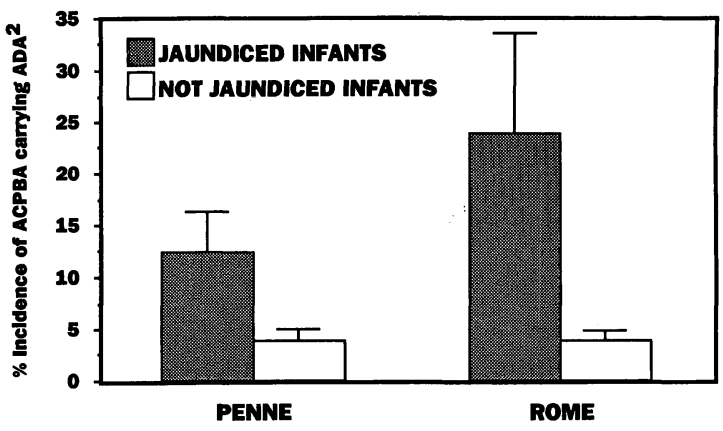

Figure 2. Incidence of $\mathrm{ACP}_{1}$ phenotype $\mathrm{BA}$ carrying $\mathrm{ADA}^{2}$ allele among jaundiced and not jaundiced infants. Vertical lines represent standard errors.

ulation of Penne than in the population of Rome. These differences may be due: (i) to ethnics background, (ii) to differences in the clinical approach especially in the administration of phototherapy, and (iii) to the possibility that jaundiced infants excluded for sampling have slightly different clinical characteristics as compared to infants included in the study.

In the sample from Rome the risk of neonatal jaundice is $41.7 \%$ for $\mathrm{ACP}_{1} \mathrm{BA}$ infants carrying $\mathrm{ADA}^{2}$ and $7.5 \%$ for other infants. Relative risk for $\mathrm{ACP}_{1} \mathrm{BA}$ infants carrying $\mathrm{ADA}^{2}$ is 5.55 and attributable risk is $34.2 \%$. In the sample from Penne and indirect estimate gives a risk of neonatal jaundice of $38.4 \%$ for $\mathrm{ACP}_{1} \mathrm{BA}$ infants carrying $\mathrm{ADA}^{2}$ and $13.8 \%$ for other infants. Relative risk is $2.78 \%$ and attributable risk $24.6 \%$.

\section{Discussion}

The present data make it extremely unlikely that the observed combined effect of $\mathrm{ACP}_{1}$ and ADA phenotypes on the incidence of neonatal jaundice may be due to sampling chance phenomena. Since the population of Penne is homogeneous, stratification can be reasonably excluded.

The positive association of jaundice with $\mathrm{ACP}_{1}$ phenotype CA previously reported by our group may be explained assuming that, since CA has a relatively high activity, flavin cofactors and glutathione reductase activity are reduced. This in turn would cause a reduction of $\mathrm{RBC}$ survival and an increase of bilirubin load. In subjects carrying $\mathrm{ADA}^{2}$, however, the highest incidence of neonatal jaundice is observed in $\mathrm{ACP}_{1}$ phenotype $\mathrm{BA}$. Since $\mathrm{ACP}_{1} \mathrm{BA}$ has a low enzymatic activity and probably a relatively high levels of flavin cofactors, some other mechanism must be assumed in order to explain the association. $\mathrm{ADA}^{2}$ carriers produce less inosine as compared to ADA 1 subjects and therefore $\mathrm{ACP}_{1}$ activity may be generally lower in ADA 2-1 than in ADA $1 . \mathrm{ACP}_{1}$ phenotype BA in the presence of $\mathrm{ADA}^{2}$ might attain very low enzymatic activities and in turn flavoenzymes and related metabolic pathways might have high levels of activity. It is known that microsomal heme oxigenase catalyses the oxidation of heme at the $\alpha$-methene bridge to form biliverdin; this step is subsequently coupled with soluble NADPH-dependent biliverdin reductase to form bilirubin [7, 16, 21]. Concentration of cofactors produced by metabolic pathways involving flavoenzymes may be rate-limiting for the heme-oxigenase complex and for the production of bilirubin in the newborns. Heme oxigenase activity and production of endogeneous $\mathrm{CO}$ in newborns should be analysed in relation to $\mathrm{ACP}_{1}$ and $\mathrm{ADA}$ phenotype in order to give support to our conjecture.

Ethnic factors may affect the severity of physiologic jaundice in full-term compatible newborns $[10,13]$. Table IV shows that the incidence of clinically significant jaundice (serum bilirubin $\geqslant 10-12 \mathrm{mg} / \mathrm{dl}$ ) in ABO compatible newborns is much lower in Negro than in White population. In Negro populations the frequency of BA-ADA 2-1 phenotype is about one fifth of that observed in Whites. Assuming that interactions similar to those observed in Italian populations are also acting in the genetic background of Blacks, from the data in table IV one can calculate that more than one third of the difference in the incidence of neonatal jaundice between the two ethnic groups may be explained by the difference in the frequency of $\mathrm{ACP}_{1} \mathrm{BA}-\mathrm{ADA}$ 2-1 genotype. The practical absence of $\mathrm{ACP}_{1}$ phenotype $\mathrm{CA}$ in Blacks may also contribute to the low incidence of jaundice in this ethnic group.

Genes for $\mathrm{ACP}_{1}$ and $\mathrm{ADA}$ are on chromosomes 2 and 20 respectively; therefore, no linkage effects are involved in the interaction between these polymorphisms.

The possibility that effects on jaundice may be due to genes linked to $\mathrm{ACP}_{1}$ and/or ADA cannot be excluded at present. However, since the functions of $\mathrm{ACP}_{1}$ and $\mathrm{ADA}$ suggest plausible biochemical mechanisms we would favour a direct 
Table IV. Frequency of $\mathrm{ACP}_{1}$ BA-ADA 2-1 phenotype in White and Negro populations and incidence of clinically significant jaundice in newborns compatible in the $\mathrm{ABO}$ system

\begin{tabular}{|c|c|c|c|c|c|c|c|c|c|}
\hline & \multicolumn{3}{|c|}{$\begin{array}{l}\text { Approximate \% } \\
\text { gene frequencies }\end{array}$} & \multirow{2}{*}{$\begin{array}{l}\begin{array}{l}\text { Expected \% } \\
\text { frequencies }\end{array} \\
\text { of } \mathrm{ACP}_{1} \mathrm{BA}- \\
\mathrm{ADA} 2-1 \\
\text { phenotype }\end{array}$} & \multicolumn{5}{|c|}{$\%$ Incidence of clinically significant neonatal jaundice } \\
\hline & $\overline{\mathbf{P}^{\mathbf{a}}}$ & $\mathrm{P}^{\mathrm{b}}$ & $\overline{\mathrm{ADA}^{2}}$ & & $\begin{array}{l}\text { U.S. A. } \\
\text { (Friedman) }\end{array}$ & $\begin{array}{l}\text { U.S.A. } \\
\text { (Kirkman) }\end{array}$ & $\begin{array}{l}\text { All } \\
\text { subjects }\end{array}$ & $\begin{array}{l}\text { Rome } \\
\text { ACP }_{1} \text { BA- } \\
\text { ADA 2-1 } \\
\text { subjects }\end{array}$ & $\begin{array}{l}\text { Other } \\
\text { types }\end{array}$ \\
\hline $\begin{array}{l}\text { Whites } \\
\text { Blacks } \\
\text { (U.S. A.) }\end{array}$ & $\begin{array}{l}27 \\
20\end{array}$ & $\begin{array}{l}67 \\
77\end{array}$ & $\begin{array}{l}7 \\
1.5\end{array}$ & $\begin{array}{l}4.7 \\
0.9\end{array}$ & $\begin{array}{r}13.3 \\
7.0\end{array}$ & $\begin{array}{r}12.5 \\
4.4\end{array}$ & $\begin{array}{l}9.3 \\
-\end{array}$ & $\begin{array}{l}41.6 \\
-\end{array}$ & $\begin{array}{l}7.5 \\
-\end{array}$ \\
\hline
\end{tabular}

involvement of $\mathrm{ACP}_{1}$ and $\mathrm{ADA}$ in the phenomenon presently described.

It is likely that metabolic variability due to enzyme polymorphism may significantly contribute to modulation of bilirubin metabolism in the critical phase of adaptation to extrauterine life. Enzyme of purine nucleotide metabolism (including ADA), $\mathrm{ACP}_{1}$ and flavoenzymes may represent a polygenic complex influencing bilirubin levels in the first few days of life and probably also other developmental variables.

\begin{abstract}
A sample of children treated by phototherapy during the neonatal period has been studied in the population of Penne (South Eastern Italy) in order to confirm the association previously reported in newborns from the population of Rome between neonatal jaundice and phenotypes of adenosine deaminase (ADA) and acid phosphatase $\left(\mathrm{ACP}_{1}\right)$.

The present data confirm that the incidence of clinically relevant jaundice is much greater in newborns of phen-
\end{abstract}

otype $\mathrm{ACP}_{1} \mathrm{BA}$ carrying $\mathrm{ADA}^{2}$ allele than in other infants.

Since $\mathrm{ACP}_{1}$ probably acts as flavin mononucleotide phosphatase and is modulated by purine nucleotides, it is likely that enzymes of purine nucleotide metabolism (including $\mathrm{ADA}), \mathrm{ACP}_{1}$ and flavoenzymes (including gluthatione reductase and enzymes of Krebs cycle), may represent a polygenic complex influencing bilirubin levels in the first few days of life.

Keywords: Acid phosphatase, adenosine deaminase, enzyme polymorphism, neonatal jaundice.

\section{Zusammenfassung}

Enzymvariabilität und neonatale Gelbsucht - zur Rolle der Adenosin-Deaminase und Säurephosphatase

In früheren Untersuchungen konnte in der Bevölkerung von Rom bei reifgeborenen Kinder mit BlutgruppenKompatibilität folgendes Phänomen beobachtet werden: Neugeborene mit $\mathrm{ACP}_{1}$ Phänotyp $\mathrm{BA}$, Träger von $\mathrm{ADA}^{2}$-Allelen zeigten häufiger eine Gelbsucht als andere Kinder $\left(\mathrm{ACP}_{1}=\right.$ Säurephosphatase Locus $1, \mathrm{ADA}^{2}=$ Adenosin-Deaminase). Diese Beobachtung ist nun an einer weiteren Untersuchungsreihe von Kindern aus einer anderen italienischen Population bestätigt worden. Wir untersuchten $56 \mathrm{Kinder}$, die in der Neonatalphase eine Phototherapie erhielten und 141 Neugeborene ohne Gelbsucht aus der Region von Penne (Südosten von Italien). Zum Vergleich werden die Daten der $225 \mathrm{Kinder}$ aus der römischen Bevölkerung gezeigt.
Tabellen II u. III, sowie Abbildung 2 zeigen, daß in beiden Populationen $\mathrm{ACP}_{1}$ Phänotyp $\mathrm{BA}$, Träger von $\mathrm{ADA}^{2}$-Allelen positiv korreliert ist mit einer klinisch bedeutsamen Gelbsucht. Der Anteil der Kinder mit der o.gen. Konstellation an Neugeborenen mit Hyperbilirubinämie betrug in Rom $23.8 \%$ und in Penne $12.5 \%$. Bei Kindern ohne Gelbsucht war der Anteil 3.4\% bzw. $3.5 \%$.

$\mathrm{ACP}_{1}$ ist ein polymorphes Enzym, welches wahrscheinlich in vivo als eine Flavin-Mononucleotid-Phosphatase fungiert. Von daher könnte es die Aktivität im KrebsZyklus modulieren und andere wichtige Enzyme wie die Glutathionreductase beeinflussen, ein Flavoenzym, das eine Schlüsselrolle bei der Formerhaltung der roten Blutkörperchen spielt. Die enzymatische Aktivität der $\mathrm{ACP}_{1}$ wird durch Purine moduliert (d.h. aktiviert oder inhi- 
biert). Der wichtigste Aspekt dieses. Befundes ist die Tatsache, daß bei der quantitativen Variation der $\mathrm{ACP}_{1^{-}}$ Aktivität die Wirkung der Alloenzyme in der Rangordnung $\mathrm{p}^{\mathrm{a}}<\mathrm{p}^{\mathrm{b}}<\mathrm{p}^{\mathrm{c}}$ zunimmt, während hinsichtlich der Modulation der Purine die Wirkung der Alloenzyme mit $\mathrm{p}^{\mathrm{c}}<\mathrm{p}^{\mathrm{a}}<\mathrm{p}^{\mathrm{b}}$ oder $\mathrm{p}^{\mathrm{b}}<\mathrm{p}^{\mathrm{a}}<\mathrm{p}^{\mathrm{c}}$ einzuordnen ist.

ADA ist ein polymorphes Enzym, welches die De-Aminierung von Adenosin zu Inosin katalysiert. Die Synthese wird durch einen autosomalen Locus mit zwei kodominanten Allelen $\mathrm{ADA}^{1}$ und $\mathrm{ADA}^{2}$ kontrolliert. Die enzymatische Aktivität nimmt in der Reihenfolge $\mathrm{ADA}^{1}>\mathrm{ADA}^{2} \mathrm{ab} . \mathrm{Da} \beta$ eine Interaktion zwischen $\mathrm{ACP}_{1}$ und ADA möglich ist, wurde durch die Beobachtung nahegelegt, da $B$ Adenosin keinen bedeutsamen Einfluß auf die $\mathrm{ACP}_{1}$-Aktivität hat, während dagegen Inosin als relativ starker Aktivator wirkt.

Ethnische Faktoren könnten den Schweregrad einer physiologischen Hyperbilirubinämie bei Reifgeborenen be- einflussen. Tatsächlich ist die Inzidenz einer klinisch bedeutsamen Gelbsucht bei Neugeborenen mit ABOKompabilität unter Negern viel niedriger als in der weiBen Population. Da die Frequenz von BA-Personen, die $\mathrm{ADA}^{2}$-Träger sind, unter Schwarzen ebenfalls geringer ist als unter Weißen, könnte dies zu der unterschiedlichen Inzidenz der neonatalen Gelbsucht bei diesen beiden ethnischen Gruppen beitragen (Tabelle IV).

Wahrscheinlich wirkt die metabolische Variabilität, bedingt durch den Enzympolymorphismus, entscheidend auf die Modulation des Bilirubinmetabolismus in der kritischen Adaptationsphase an das extrauterine Leben ein. Enzyme des Purinstoffwechsels (incl. ADA), $\mathrm{ACP}_{1}$ und Flavoenzyme widerspiegeln einen polygenen Komplex, der die Bilirubinspiegel in den ersten Lebenstagen sowie vielleicht auch andere Variabilitäten in der Entwicklung beeinflußt.

Schlüsselwörter: Adenosin-Deaminase, Enzympolymorphismus, neonatale Gelbsucht, Säurephosphatase.

\section{Résumé}

Variabilité enzymatique et ictère néonatal. Role de l'adénosine déaminase et de la phosphatase acide

Des études antérieures sur la population de Rome ont montré que chez les nouveaux-nés compatibles à terme, l'incidence d'ictères chez les nouveaux-nés de phénotype $\mathrm{ACP}_{1}$ (phosphatase acide locus 1) BA portant l'allèle $\mathrm{ADA}^{2}$ (adénosine déaminase) est beaucoup plus élevée que chez les autres enfants. Cette observation est maintenant confirmée dans une nouvelle série d'enfants issus d'autre population italienne.

On a étudié un échantillon de 56 enfants traités par photothérapie en période néonatale et un échantillon de 141 nouveaux-nés sans ictère provenant de la population de Penne (Sud Est de l'Italie). A titre de comparaison, les données des séries antérieure de 225 enfant romains sont rapportées.

Les tableaux II et III ainsi que la figure 2 montrent que dans les 2 populations le phénotype $\mathrm{ACP}_{1} \mathrm{BA}$ sortant l'allèle $\mathrm{ADA}^{2}$ est associé positivement avec lictère néonatal clinique.

Parmi les enfants ictériques la proportion de Phénotype $\mathrm{ACP}_{1} \mathrm{BA}$ portant l'allèle $\mathrm{ADA}^{2}$ est de $23,8 \%$ à Rome et de $12,5 \%$ à Penne; Parmi les enfants sans ictère, les proportions sont restpectivement de $3,4 \%$ et de $3,5 \%$.

$\mathrm{ACP}_{1}$ est une enzyme polymorphique qui agit vraisemblablement in vivo comme une phosphatase mononucléotide flavine; elle peut donc moduler l'activité du cycle de Krebs et d'autres enzymes importantes telles que la glutathion réductase, flavoenzyme qui exerce un rôle clé dans la maintenance de l'intégrité des globules rouges. L'activité enzymatique de l'ACP ${ }_{1}$ est modulée (activation ou inibition) par les purines. L'aspect le plus important de ces éléments est le fait que pour la variation quantitative de l'activité $\mathrm{ACP}_{1}$, la contribution des alloenzymes augmente dans l'ordre $\mathrm{p}^{\mathrm{a}}<\mathrm{p}^{\mathrm{b}}<\mathrm{p}^{\mathrm{c}}$ alors que pour l'effet de modulation des purines, la contribution des alloenzymes peut être soit $\mathrm{p}^{\mathrm{c}}<\mathrm{p}^{\mathrm{a}}<\mathrm{p}^{\mathrm{b}}$ soit $\mathrm{p}^{\mathrm{b}}<\mathrm{p}^{\mathrm{a}}<\mathrm{p}^{\mathrm{c}}$.

ADA est une enzyme polymorphique qui catalyse la désamination d'adénosine en inosine. Sa synthèse est contrôlée par un locus autosomique avec deux allèles codominants $\mathrm{ADA}^{1}$ et $\mathrm{ADA}^{2}$. L'activité enzymatique diminue dans l'ordre $\mathrm{ADA}^{1}>\mathrm{ADA}^{2}$. L'étude d'une interaction possible entre $\mathrm{ACP}_{1}$ et $\mathrm{ADA}$ a été suggéré par l'observation du fait que l'adénosine ne manifeste pas d'effets appréciables sur l'activité $\mathrm{ACP}_{1}$, alors que, au contraire, l'inosine est un activateur relativement puissant.

Des facteurs ethniques peuvent affecter la sévérité de l'ictère physiologique chez les nouveaux-nés compatibles à terme. En fait, l'incidence de l'ictère significatif cliniquement chez les nouveaux-nés compatibles dans le système $\mathrm{ABO}$ est beaucoup plus faible chez les noirs que chez les blancs. Puisque la fréquence des sujets BA portant $\mathrm{ADA}^{2}$ est également beaucoup plus faible chez les noirs que chez les blancs, celà peut contribuer à la différence de l'incidence de l'ictère néonatal entre les deux groupes ethniques (tableau IV).

Il est vraisembable que la variabilité métabolique secondaire au polymorphisme enzymatique peut contribuer significativement à une modulation du métabolisme de la bilirubine pendant la phase critique d'adaptation à la vie extrautérine. Les enzymes du métabolisme des nucléotides puriniques ( $\mathrm{y}$ compris $\mathrm{ADA}$ ), $\mathrm{ACP}_{1}$ et Flavoenzymes représentent un complexe polygénique qui influence les taux de bilirubine au cours des premiers jours de vie et vraisemblablement également d'autres variables développementales.

Mots-clés: Adénosine déaminase, ictère néonatal, phosphatases acide, polymorphisme enzymatique. 
Acknowledgements: We wish to thank Prof. F. J. RoHLF for helpful discussion. This work was supported by GraNTs from M.P. I. (Forty per cent Found) and CNR (grant $n^{\circ} 87.01249 .11$ )

\section{References}

[1] Battistuzzi G, R Scozzari, P Santolamazza et al: Comparative activity of red cell adenosine deaminase allelic forms. Nature 251 (1974) 711

[2] BoTTINI E: The relation between erythrocyte acid phosphatase and gestational length: present status. Early Human development 10 (1985) 309

[3] Bottini E, E Carapella, F Gloria-Bottini et al: Neonatal jaundice: a search for interaction between erythrocyte acid phosphatase and adenosine deaminase polymorphisms. Disease Markers 2 (1984) 469

[4] Bottini E.,E Carapella, R Scacchi et al: Serum haptoglobin appearance during neonatal period is associated with acid phosphatase $\left(\mathrm{ACP}_{1}\right)$ phenotype. Early Human Development 10 (1985) 237

[5] BotTini E, P LuCarelli, V Bastianon et al: Erythrocyte acid phosphatase polymorphism and haemolysis. J Med Genet 9 (1972) 434

[6] Bottini E, R SCACChi, F GloRia-Bottini et al: Neonatal jaundice and erythrocyte acid phosphatase phenotype. Lancet 1 (1976) 918

[7] BRown SB, FGJ KING: The mechanism of Haeme catabolism. Biochem J 170 (1978) 297

[8] Carapella E, R Pascone, MG Gori et al: The genetic component of quantitative perinatal variables. An analysis of relations between erythrocyte acid phosphatase phenotype and birth weight, gestational age and serum bilirubin level in the first day of life. J Perinat Med 8 (1980) 42

[9] Edwards YH, DA Hopkinson, H Harris: Adeinosine deaminase isozymes in human tissues. Am Hum Genet 35 (1971) 207

[10] Friedman L, PJ Lewis, P Clifton et al: Factors influencing the incidence of neonatal jaundice. Brit Med J 1 (1978) 1235

[11] Hopkinson DA, N Spencer, H Harris: Red cell acid phosphatase variants: a new human polymorphism. Nature 199 (1963) 969
[12] Hopkinson DA, N SPENCER, H HaRris: Genetic studies on human red cell acid phosphatase. Am J Hum Genet 16 (1964) 141

[13] KIRKMAN HN: Further evidence for a racial difference in frequency of ABO hemolytic disease. J Pediat 90 (1977) 717

[14] Mansfield E, GF Sensabaugh: Red cell acid phosphatase modulation of activity by purines. In: Brewer GJ (ed.): The Red Cell (Progr Biol Res 21) Alan R Liss Inc, New York 1978

[15] MohrenWeiser HW, JE NovotnY: ACP ${ }^{\text {gua-1-1 }}$ A low activity variant of human erythrocyte acid phosphatase: association with increased glutathione reductase activity. Am J Hum Genet 34 (1982) 425

[16] RAFFIN SB, CH Woo, KT Roost et al: Intestinal absorption of hemoglobin iron-heme cleavage by mucosal heme oxygenase. J Clin Invest 54 (1974) 1344

[17] Sensabaugh GF, VL Golden: Phenotype dependence in the inhibition of red cell acid phosphatase (ACP) by folates. Am J Hum Genet 30 (1978) 553

[18] SoKal RR, FJ RoHLF: Biometry. WF Freeman and Company, New York 1981

[19] SPENCER N, D Hopkinson, H Harris: Adenosine deaminase polymorphism in man. Am Hum Genet 32 (1968) 9

[20] SWAllow DM, S PoveY, H HaRris: Activity of 'red cell' acid phosphatase locus in other tissues. Ann Hum Genet 37 (1973) 31

[21] Tenhunen R, HS MarVer, R SchmiD: Microsomal Heme Oxigenase. J Biol Chem 244 (1969) 6388

Received August 11, 1986. Revised February 13, 1989. Accepted February 16, 1989.

Egidio Bottini, M. D.

Professor of Pediatrics and Genetics

Chair of Human Development

2nd University of Rome School of Medicine

Via Orazio Raimondo

I-00173 Rome, Italy 